Hitoshi Morikawa MD, Hiroyuki Mima MD, Hisashi Fujita MD, Seigo Mishima MD

\title{
Oxygen embolism due to hydrogen peroxide irrigation during cervical spinal surgery
}

\begin{abstract}
Hydrogen peroxide is used to cleanse and irrigate wounds. As it decomposes immediately into water and oxygen on contact with organic tissue, it is usually regarded as a safe agent. We report a case of oxygen embolism associated with hydrogen peroxide irrigation of the surgical field during anterior fusion of the cervical vertebrae. It was accompanied by precipitous hypotension and decrease in pulse oximetry oxygen saturation and end-tidal $\mathrm{CO}_{2}$ tension. Semi-closed spaces formed under the apatite dowel and between the apatite dowel and vertebral bodies may have precipitated the absorption of oxygen bubbles into the vasculature. Although this case was associated with a rapid recovery and uneventful sequelae, it discourages the use of hydrogen peroxide in this procedure because of the potential hazards including cardiovascular collapse.
\end{abstract}

On utilise le peroxyde d'hydrogène pour nettoyer et irriguer les plaies. Comme il se décompose instantanément en eau et en oxygène au contact d'un tissus organique, on le considère inoffensif. Nous rapportons un cas d'embolie associée à l'irrigation d'une plaie au peroxyde d'hydrogène pendant une fusion cervicale antérieure. L'embolie s'est manifestée par une hypotension subite et une chute de la saturation en oxygène et du $\mathrm{CO}_{2}$ téléexpiratoire. La présence d'espaces semi-clos sous le pivot d'apatite et entre le pivot d'apatite et le corps vertébral peut avoir précipité l'absorption des bulles d'oxygène dans l'arbre vasculaire. Bien que ce malade ait récupéré rapidement et sans séquelles, il est préférable de ne pas utiliser le peroxyde d'hydrogène pendant cette intervention à cause du danger inhérent de collapsus vasculaire.

\section{Key words}

COMPLICATIONS: embolism;

EMBOLISM: oxygen;

OXYGEN: hydrogen peroxide.

From the Department of Anesthesia, Ohtsu Municipal

Hospital, Shiga, Japan.

Address correspondence to: Dr. Hitoshi Morikawa,

Department of Biophisics, Neuroinformation Research Institute, Kanazawa University School of Medicine, 13-1

Takaramachi, Kanazawa 920, Japan.

Accepted for publication 1st November, 1994.
Venous oxygen embolism due to application of hydrogen peroxide to semi-closed spaces has been reported previously. ${ }^{1-5}$ We describe a case of gas embolism caused by oxygen liberated from hydrogen peroxide used for irrigation of the surgical field during cervical spinal surgery. This case illustrates the potential formation of semi-closed spaces during this type of surgery, which renders it susceptible to oxygen embolism when hydrogen peroxide is used.

\section{Case report}

The case involved a 54-yr-old, 52-kg man with an 18mo history of left shoulder pain and numbness of the left 1st-3rd fingers. Myelography, CT scan and MRI scan revealed herniation of the $C_{5 / 6}$ intervertebral disc. He was scheduled for anterior fusion of cervical vertebrae at the $\mathrm{C}_{5 / 6}$ level. Medical history revealed only mild hypertension without medication. Preoperative laboratory data, chest $x$-ray and ECG were within normal limits.

Preoperative medication consisted of midazolam 7.5 $\mathrm{mg}$ and atropine $0.5 \mathrm{mg} \mathrm{im}$. Intraoperative monitoring included intra-arterial blood pressure, ECG (lead II), pulse oximetry and capnography. The patient was placed in the supine position and anaesthesia was induced with droperidol $2.5 \mathrm{mg}$, diazepam $5 \mathrm{mg}$ and thiopentone 150 $\mathrm{mg} i v$ and muscle relaxation was produced with pancuronium $6 \mathrm{mg} \dot{w}$. After tracheal intubation, anaesthesia was maintained with oxygen, nitrous oxide and enflurane, $0.2-0.5 \%$ inspired. Pancuronium was given intermittently to maintain muscle paralysis. Blood gas analysis five minutes after induction of anaesthesia showed pHa 7.424, $\mathrm{PaO}_{2} 148.8 \mathrm{mmHg}(19.84 \mathrm{kPa})$ and $\mathrm{PaCO}_{2} 35.8 \mathrm{mmHg}$ $(4.77 \mathrm{kPa})$ with $\mathrm{FIO}_{2}$ 0.33.

The anaesthetic course was uneventful. Systolic arterial pressure was stable around $100 \mathrm{mmHg}$. After inserting the apatite dowel in the drilled hole, the surgeon irrigated the surgical field with approximately $30 \mathrm{ml}$ hydrogen peroxide $3 \%$. Profuse bubbles were formed as usual. About $30 \mathrm{sec}$ later, there was a sudden decrease in systolic arterial pressure to $70 \mathrm{mmHg}$. Oxygen saturation $\left(\mathrm{SpO}_{2}\right)$ decreased from $99 \%$ to $90 \%$ and end-tidal $\mathrm{CO}_{2}$ tension $\left(\mathrm{PeTCO}_{2}\right)$ from $35 \mathrm{mmHg}(4.7 \mathrm{kPa})$ to $22 \mathrm{mmHg}(2.9$ 
$\mathrm{kPa}$ ). Blood gas analysis at this time showed $\mathrm{pHa} 7.336$, $\mathrm{PaO}_{2} 58.3 \mathrm{mmHg}(7.77 \mathrm{kPa}), \mathrm{PaCO}_{2} 44.4 \mathrm{mmHg}(5.92$ $\mathrm{kPa}$ ) with $\mathrm{FIO}_{2}$ 0.33. Enflurane was turned off immediately and the lungs were ventilated with $100 \%$ oxygen. The anaesthetic machine and the breathing systems were checked to ensure proper functioning. There was no massive bleeding in the surgical field at the time of hydrogen peroxide irrigation and no drug has been administered prior to the decrease in blood pressure. Oxygen embolism was suspected because of the temporal relationship of hydrogen peroxide irrigation and the onset of the signs. The patient was swiftly placed in the Trendelenburg position and the surgeon aspirated the oxygen bubbles from the surgical field which was flooded with normal saline. Systolic arterial pressure increased to over $100 \mathrm{mmHg}$ and $\mathrm{SpO}_{2}$ returned to $99 \%$ within one minute. The operation ended uneventfully. Emergence and recovery from anaesthesia were without incident. Blood gas analysis obtained after extubation showed $\mathrm{pHa} 7.313, \mathrm{PaO}_{2} 206.9 \mathrm{mmHg}(27.59 \mathrm{kPa})$, $\mathrm{PaCO}_{2} 49.4 \mathrm{mmHg}(6.59 \mathrm{kPa})$ breathing oxygen, 5 $\mathrm{L} \cdot \mathrm{min}^{-1}$, by face mask. The patient showed no evidence of neurological sequelae and was discharged from hospital with his original symptoms improved.

\section{Discussion}

This report illustrates a case of venous gas embolism which seemed to be caused by oxygen liberated from hydrogen peroxide used to irrigate the surgical field during anterior fusion of the cervical vertebrae.

Hydrogen peroxide is rapidly decomposed into water and oxygen on contact with organic tissue or blood where abundant catalase is present. The liberated oxygen microbubbles cause mechanical removal of tissue debris and have a weak germicidal effect. It is also known to produce vasoconstriction. ${ }^{1}$ Moreover, according to the neurosurgeons in our hospital, when it is applied to the surgical field and then aspirated, the tissue surface will be faintly whitened and the bleeding points will stand out.

One $\mathrm{ml}$ hydrogen peroxide $3 \%$ releases approximately $10 \mathrm{ml}$ oxygen. ${ }^{6}$ The danger of oxygen embolism exists when the liberated oxygen bubbles or hydrogen peroxide enter blood vessels. There are reports of oxygen embolization to the portal venous system after ingestion of hydrogen peroxide. ${ }^{7-9}$ One fatality was reported in a twoyear-old boy who ingested $120-180 \mathrm{ml}$ hydrogen peroxide $35 \% .{ }^{8}$ There are also several reports of oxygen embolization due to application of hydrogen peroxide to the surgical field. ${ }^{1-5}$ A large volume of oxygen bubbles in the venous system can result in a decrease in cardiac output. ${ }^{2,4,5}$ In addition, oxygen bubbles can traverse the lungs to cause systemic embolism including embolism to coronary and cerebral arteries. ${ }^{5}$ Irrigation of the bleeding, friable tissue in the semi-closed space under pressure is said to be especially dangerous. In the present case, semiclosed spaces may have formed under the apatite and between the apatite and the vertebral bodies. Furthermore, haemostasis might have been insufficient so that access to the circulation could occur and a large amount of oxygen bubbles or hydrogen peroxide absorbed into the venous system.

Sudden onset of hypotension, hypoxia and a decrease in $\mathrm{PETCO}_{2}$ immediately after hydrogen peroxide irrigation and the rapid recovery from these signs strongly suggests gas embolism due to oxygen liberated from hydrogen peroxide. Since rapid treatment was indicated there was no time to place a precordial stethoscope beyond the surgical field to hear the classic millwheel murmur. Treatment of venous air embolism includes discontinuation of nitrous oxide and administration of $100 \%$ oxygen, aspiration of air if a central venous or pulmonary artery catheter is in place and placing the patient in the Trendelenburg position with the left side down if possible. Flooding the field with saline will prevent further air absorption.

The main purpose of hydrogen peroxide irrigation of the surgical field by the neurosurgeons in our hospital is not to prevent postoperative infection but to identify bleeding points and secure complete haemostasis, as postoperative haematomata and consequent obstruction of the upper airway is the most serious sequel of anterior cervical vertebrae fusion. Topical antibiotics or irrigation with povidone iodine may thus be more effective in preventing postoperative infection, which is a rare complication of this surgery. Although oxygen embolism due to hydrogen peroxide irrigation is a rare complication during anterior cervical fusion, (the present case was the first in $>800$ operations in our hospital), we discourage its use considering the potential serious consequences including circulatory collapse. ${ }^{2,4,5}$

In summary, we report a case of oxygen embolism after hydrogen peroxide irrigation during anterior fusion of the cervical vertebrae. This case re-emphasizes the potential hazard of the application of hydrogen peroxide to semi-closed spaces and discourages its use in this procedure.

\section{References}

1 Shah J, Pedemonte MS, Wilcock MM. Hydrogen peroxide may cause venous oxygen embolism (Letter). Anesthesiology 1984; 61: 631-2.

2 Gerrish SP. Gas embolism due to hydrogen peroxide (Letter). Anaesthesia 1985; 40: 1244.

3 Sleigh JW, Linter SPK. Hazards of hydrogen peroxide. BMJ 1985; 291: 1706. 
4 Tsai $S-K$, Lee $T-Y$, Mok MS. Gas embolism produced by hydrogen peroxide irrigation of an anal fistula during anesthesia. Anesthesiology 1985; 63: 316-7.

5 Bassan $M M$, Dudai $M$, Shalev $O$. Near-fatal systemic oxygen embolism due to wound irrigation with hydrogen peroxide. Postgrad Med J 1982; 58: 448-50.

6 Fuson RL, Kylstra JA, Hochstein P, Saltzman HA. Intravenous hydrogen peroxide infusion as a means of extrapulmonary oxygenation. Clin Res 1967; 15: 74.

7 Luu TA, Kelley MT, Strauch JA, Avradopoulos K. Portal vein gas embolism from hydrogen peroxide ingestion. Ann Emerg Med 1992; 21: 1391-3.

8 Christensen DW, Faught WE, Black RE, Woodward GA, Timmons $O D$. Fatal oxygen embolization after hydrogen peroxide ingestion. Crit Care Med 1992; 20: 543-4.

9 Rackoff WR, Merton DF. Gas embolism after ingestion of hydrogen peroxide. Pediatrics 1990; 85: 593-4. 